\title{
Kaempferia galanga L. sebagai Anti-Inflamasi dan Analgetik
}

\author{
Reandy Ilham Andriyono \\ Fakultas Kedokteran, Universitas Lampung, Indonesia \\ Email: ilhamandriyono@yahoo.co.id
}

\begin{abstract}
Kaempferia galanga L. as Anti-Inflammatory and Analgesic. Galangal (Kaempferia galanga $l$ ) is an herb that is often used in everyday life and widely used as a spice, food flavoring, and local tonic ingredients called 'Jamu'. Galangal is a source of zinc, starch, ethyl ester, paraeumarin, borneaol, minerals, cinnamic acid, and other nutrients that are widely used in traditional medicine applications for a long time, especially in Southeast Asia. Besides that, it has medical functions, one of which is anti-inflammatory. Inflammation is a normal protective response to tissue injuries caused by physical trauma, damaging chemicals or microbiological substances. Inflammation can also be interpreted as the body's effort to activate or damage organisms that attack, eliminate irritants and regulate tissue repair. Signs of inflammation are redness, swelling, heat, and pain. Many chemical drugs are used to prevent inflammation, one of which is that modern drugs commonly used as anti-inflammatory drugs are NSAIDs (Non-Steroid Anti-inflammatory) Mechanism as an anti-inflammatory activity by elevating anti-inflammatory production IL-10, reducing pro-inflammatory IL-6 or TNF-a production, reducing the expression of iNOS and COX-2, inhibition of PG synthesis, Kaempferia galanga $L$ also inhibits several inflammatory mediators TNF- $\alpha$, IL- $1 \beta$, and Nitric Oxide (NO) and angiogenesis.
\end{abstract}

Keywords: Analgetic, Anti-inflammatory, Kaempferia galanga L.

\begin{abstract}
Abstrak: Kaempferia galanga L. Sebagai Anti-Inflamasi dan Analgetik. Kencur (Kaempferia galanga $l$ ) merupakan ramuan yang sering digunakan dalam kehidupan sehari hari dan banyak digunakan sebagai bumbu, penyedap makanan, dan bahan tonik lokal yang disebut 'Jamu'. Kencur juga merupakan sumber seng, pati, etil ester, paraeumarin, borneaol, mineral, asam sinamat, dan nutrisi lain yang banyak digunakan dalam aplikasi obat tradisional sejak lama, terutama di Asia Tenggara. Selain itu, kencur memiliki fungsi medis, salah satunya sebagai anti-inflamasi. Inflamasi merupakan suatu respon protektif normal terhadap luka jaringan yang disebabkan trauma fisik, zat kimia yang merusak atau zat-zat mikrobiologi. Inflamasi dapat juga diartikan sebagai usaha tubuh untuk mengaktivasi atau merusak organisme yang menyerang, menghilangkan zat iritan dan mengatur perbaikan jaringan. Tanda-tanda inflamasi adalah kemerahan, bengkak, panas dan nyeri. Banyak obat kimia yang digunakan untuk mencegah inflamasi tersebut, salah satunya ialah obat modern yang biasa digunakan sebagai antiinflamasi adalah obat golongan AINS (Antiinflamasi Non Steroid). Mekanisme sebagai aktivitas anti-inflamasi dengan meningkatkan produksi anti-inflamasi IL-10, mengurangi produksi IL-6 atau TNF-pro-inflamasi, mengurangi ekspresi iNOS dan COX-2, menghambat sintesis PG, Kaempferia galanga L juga menghambat beberapa mediator inflamasi TNF- $\alpha$, IL-1 $\beta$, dan Nitric Oxide (NO) dan angiogenesis.
\end{abstract}

Kata kunci: Analgetik, Anti-inflamasi, Kaempferia galanga L.

\section{PENDAHULUAN}

Indonesia merupakan salah satu negara mega biodiversity dengan jumlah tanaman obat sekitar 40.000 jenis, namun baru sekitar 2,5\% obat tradisional yang berasal dari tanaman yang mengandung senyawa aktif. Hal itu dibuktikan dengan semakin banyaknya penelitian mengenai tanaman yang digunakan sebagai obat-obatan tradisional dan sistem pengobatan tradisional. Penggunaan tumbuhan obat ini diharapkan memiliki nilai ekonomi yang dapat mengembangkan pembudidayaan dan pengolahan tanaman obat di masa yang akan datang.

Rasa sakit pada tubuh sering kita rasakan dalam kehidupan sehari-hari. Hal tersebut dapat terjadi jika organ tubuh, otot, atau kulit terluka oleh benturan, penyakit, kram, atau bengkak yang akan menimbulkan rasa nyeri. Obat yang banyak digunakan untuk mengatasi nyeri disebut analgetik. Seiring berjalannya waktu, peran obat semakin diperlukan dalam masyarakat, sehingga produsen obat-obatan sintetik semakin merajalela di pasaran. Dampaknya berupa kenaikan harga 
obat yang semakin tidak terkendali. Hal inilah yang mendorong masyarakat untuk bergeser ke arah gaya hidup back to nature (pengobatan secara alami). Salah satu tanaman yang banyak digunakan oleh masyarakat Indonesia sebagai obat tradisional adalah kencur. Sukmono (2009) menyatakan bahwa rimpang kencur telah sering dimanfaatkan sebagai obat penghilang rasa sakit dan antiinflamasi oleh masyarakat Indonesia.

Kencur (Kaempferia galanga L.) merupakan salah satu dari lima jenis tumbuhan yang dikembangkan sebagai tanaman obat asli Indonesia. Kencur merupakan tanaman obat yang bernilai ekonomis cukup tinggi sehingga banyak dibudidayakan. Bagian rimpangnya digunakan sebagai bahan baku industri obat tradisional, bumbu dapur, bahan makanan, maupun minuman penyegar lainnya (Rostiana, et al., 2003). Kencur adalah tanaman dari keluarga Zingiberaceae, yaitu ramuan kecil yang tumbuh subur di daerah dataran rendah atau pegunungan yang memiliki tanah yang rapuh. Secara empirik, kencur berkhasiat sebagai obat untuk batuk, gatal-gatal pada tenggorokan, perut kembung, mual, masuk angin, pegal-pegal, pengompres bengkak/radang, tetanus dan penambah nafsu makan. Sulaiman, et al (2007) juga melaporkan bahwa ekstrak daun kencur mempunyai aktivitas antiinflamasi yang diuji pada radang akut yang diinduksi dengan karagenan. Selain itu, rimpang kencur dapat digunakan sebagai untuk hipertensi, rematik, dan asma.

Tanaman kencur khususnya bagian rimpang dapat digunakan sebagai antiinflamasi. Rimpang kencur mengandung flavonoid, saponin, dan minyak atsiri yang dapat berfungsi sebagai antiinflamasi. Antiinflamasi pada kencur merupakan tipe anti inflamasi non steroid. Flavonoid dapat menghambat jalur metabolisme asam arakidonat, pembentukan prostalglandin dan pelepasan histamin pada radang. Saponin bersifat seperti detergen yang diduga mampu berinteraksi dengan banyak membran lipid seperti fosfolipid yang merupakan perkusor prostalglandin mediator inflamasi lainnya. Minyak atsiri dapat menghambat agregasi platelet dengan cara menghambat pembentukan tromboksan sehingga juga berperan dalam efek antiinflamasi.

Kencur adalah sumber seng, pati, etil ester, paraeumarin, borneaol, mineral, asam sinamat, dan nutrisi lain yang banyak digunakan dalam aplikasi obat tradisional sejak lama, terutama di Asia Tenggara. Konstituen kimia utama dari minyak atsiri yang diekstraksi dari rimpang kering adalah etil-p-metoksisinamat $(31,77 \%)$, metilsinamat $(23,23 \%)$, carvone
$(11,13 \%)$, eucalyptol $(9,59 \%)$ dan pentadekana $(6,41 \%)$. Konstituen lain dari rimpang adalah cineol, borneol, 3-carene, camphene, kaempferal, cinnamaldehyde, asam pmethoxycinnamic, etil sinamat dan etil p-metoksi sinamat. Selain sebagai antioksidan dan antikanker, kencur juga memiliki kemampuan untuk menghambat proses inflamasi dan analgesik (pereda nyeri) (Kusumawati dan Yusuf, 2011).

Minyak atsiri kencur memiliki aktivitas terhadap bakteri Gram positif (Staphylococcus aureus ATCC 25923, Streptococcus faecalis dan Bacillus subtilis), Gram negatif (Salmonella typhi, Shigella flexneri, dan Escherichia coli ATCC 25922), dan khamir (Candida albicans) (Tewtrakul \& Subhadhirasakul, 2008). Efek vasorelaksan dari etil sinamat yaitu komponen utama dari kencur dapat mengurangi hipertensi. Efek terapeutik lainnya yaitu sebagai relaksan otot polos yang digunakan pada pengobatan angina, asma, dan kejang otot (Othman, et al., 2006). Ekstrak etanol dari Kaempferia galanga $L$ juga mempunyai aktivitas sebagai analgesik dan antiinflamasi (Mohanbabu, et al., 2011). Selain itu, ekstrak heksan dari Kaempferia galanga $L$ mempunyai aktivitas sebagai sedatif (Huang, et al., 2008).

Batang kencur juga memiliki efek antimikroba yang mampu menghambat bakteri dan jamur pada zona hambatnya dan memiliki aktivitas antioksidan. Kencur memiliki aktivitas sebagai antiinflamasi dan analgesik (Vittalrao et al., 2011) dan kandungan minyak atsiri sebagai antiinflamasi (Hasanah, et al.,2011). Kencur sering digunakan sebagai pengobatan tradisional di Asia Tropika untuk mengobati pembengkakan, encok, batuk, disentri, diare dan sakit perut. Penelitian dilakukan untuk mendukung klaim penggunaan tradisional pada ekstrak kencur, seperti menunjukkan menaticidal, obat nyamuk dan larvasida, antimikroba, vasorelaksan, anti neoplastik, anti alergi, antioksidan, analgesik dan efek penyembuhan luka (Umar, et al., 2012).

Selain itu kencur mampu mengobati proses penyembuhan luka bakar dari ekstrak alkohol Kaempferia galanga $L$ pada tikus galur wistar. Ekstrak etanol Kaempferia galanga $L$ dapat mempercepat proses epitelisasi pada jaringan luka dengan memfasilitasi proliferasi sel epitel, memiliki efek prohealing yang baik, dan salah satu komponen dari kencur yaitu flavonoid yang berperan sebagai antioksidan yang merupakan komponen penting dalam penyembuhan luka (Tara, et al., 2006).

Tujuan dari penulisan ini yaitu untuk mengetahui alternatif bahan yang dapat 
digunakan sebagai antiinflamasi dan analgesik pada dunia pengobatan kedokteran.

\section{PEMBAHASAN}

\section{Respon Inflamasi}

Kurkuminoid merupakan bahan aktif penting yang bertanggung jawab atas aktivitas biologis dari kencur. Aktivitas utama kurkuminoid adalah sebagai antiinflamasi. Gugus-gugus hidroksi pada kurkumin sangat penting peranannya dalam aktivitas antiinflamasi (Majeed, 1995). Kurkumin memiliki kemampuan untuk menghambat aktivasi mediator nyeri yaitu melalui ikatan dengan enzim siklooksigenase-2 dan lipooksigenase (Bengmark, 2006).

Inflamasi merupakan suatu respon protektif normal terhadap luka jaringan yang disebabkan trauma fisik, zat kimia yang merusak atau zat-zat mikrobiologi. Inflamasi dapat juga diartikan sebagai usaha tubuh untuk mengaktivasi atau merusak organisme yang menyerang, menghilangkan zat iritan dan mengatur perbaikan jaringan. Tanda-tanda inflamasi adalah kemerahan, bengkak, panas dan nyeri. Banyak obat kimia yang digunakan untuk mencegah inflamasi trsebut, salah satunya ialah obat modern yang biasa digunakan sebagai antiinflamasi adalah obat golongan AINS (Antiinflamasi Non Steroid) (Hasanah, et al., 2011).

Radang atau inflamasi merupakan respon protektif setempat yang ditimbulkan oleh cedera atau kerusakan pada jaringan yang berfungsi untuk menghancurkan, mengurangi, atau melokalisasi (sekuster) baik agen pencedera maupun jaringan yang cedera itu. Tanda-tanda pokok peradangan akut mencakup pembengkakan/edema, kemerahan, panas, nyeri, dan perubahan fungsi. Hal-hal yang terjadi pada proses radang akut sebagian besar dimungkinkan oleh pelepasan berbagai macam mediator kimia, antara lain amina vasoaktif, protease plasma, metabolit asam arakhidonat dan produk leukosit (Erlina, et al., 2007).

Terapi topikal merupakan salah satu metode pengobatan yang sering digunakan dalam bidang dermatologis, contohnya salep yang merupakan sediaan semi solid yang dapat digunakan pada kulit maupun mukosa. Kelebihan dari sediaan salep ini adalah mempunyai bentuk yang lunak, halus, homogen, dan mudah dioleskan, sehingga dapat digunakan untuk kulit yang teriritasi, inflamasi dan ekskoriasi, sebagai bahan pembawa substansi obat untuk pengobatan kulit, sebagai bahan pelumas pada kulit, sebagai pelindung untuk kulit (mencegah kontak permukaan kulit dengan larutan berair) dan sebagai obat luar (Asmara et al., 2012). Penelitian yang dilakukan oleh (Buang, 2012) bahwa ekstrak etanol rimpang kunyit dalam bentuk sediaan salep dengan konsentrasi $4 \%$ dapat memberikan efek antiinflamasi yang tidak berbeda nyata dengan kontrol positifnya.

Mekanisme pertahanan fisiologis utama yang dikenal sebagai peradangan membantu melindungi tubuh dari rangsangan berbahaya, mengakibatkan pembengkakan atau edema jaringan, rasa sakit, atau bahkan kerusakan sel. Tujuan utama mekanisme ini adalah untuk memperbaiki dan mengembalikan jaringan yang rusak ke keadaan sehat. Gangguan sel terjadi selama proses peradangan yang mengarah pada pelepasan asam arakidonat, selanjutnya mengalami dua jalur metabolisme yang dikenal sebagai cyclooxygenase. (COX) dan jalur lipoksigenase (LOX). Jalur COX terdiri dari cyclooxygenase-1 (COX-1) dan cyclooxygenase2 (COX-2), sedangkan 5-lipoxygenase (5-LOX), 12-lipoxygenase (12-LOX), dan 15-lipoxygenase (15-LOX) adalah contoh jalur LOX. Produk dari jalur COX adalah prostaglandin (mediator peradangan akut) dan tromboksan, sedangkan yang dari jalur LOX adalah leukotrien dan asam lemak hidroperoksi (Mueller, et al., 2010).

Saat ini, obat antiinflamasi nonsteroid (NSAID) seperti ibuprofen, aspirin, diklofenak, dan celecoxib banyak digunakan untuk pengobatan peradangan. Obat-obatan ini menunjukkan sifat anti-inflamasi dengan menghambat aktivitas COX-1 dan dengan demikian mencegah sintesis protein. Namun, kekhawatiran utama adalah bahwa NSAID dapat menyebabkan berbagai efek samping seperti komplikasi gastrointestinal. Mempertimbangkan hal ini, pencarian obat baru dengan sifat antiinflamasi dari tanaman obat dengan bebas atau lebih sedikit efek samping sangat dibutuhkan untuk industri farmasi (Izzany, et al., 2018).

Peradangan akut dapat berkembang dalam hitungan menit hingga jam dan berlangsung selama berhari-hari. Peradangan kronis adalah proses yang mengambil alih dari peradangan akut jika infeksi tidak dihilangkan atau cedera jaringan yang berkepanjangan. Biasanya melibatkan rekrutmen dan aktivasi monosit dan limfosit. Situs inflamasi kronis juga mengalami perbaikan jaringan, dengan cara melakukan proses angiogenesis dan fibrosis (Riasari, et al., 2016).

Peradangan adalah bentuk pertahanan yang luas yang secara luas didefinisikan sebagai 
respons spesifik terhadap kerusakan jaringan dan digunakan oleh sistem imun bawaan dan adaptif untuk memerangi pengganggu patogen. Peradangan adalah reaksi biologis terhadap homeostasis jaringan yang terganggu. Pada tingkat dasarnya, peradangan adalah proses penghancuran jaringan yang melibatkan perekrutan produk diferensiasi sel darah, seperti protein plasma, cairan, dan leukosit, ke dalam jaringan yang terganggu. Migrasi ini difasilitasi oleh perubahan dalam pembuluh darah lokal yang menyebabkan vasodilatasi, peningkatan permeabilitas pembuluh darah, dan peningkatan aliran darah (Abbas, et al., 2015).

Peradangan memainkan peran penting dalam berbagai penyakit, seperti rheumatoid arthritis, atherosclerosis dan asma, yang semuanya menunjukkan prevalensi tinggi secara global. Selama respons inflamasi, mediator, seperti sitokin pro-inflamasi, termasuk interleukin IL-1, faktor nekrosis tumor (TNF), interferon (IFN)-c, IL-6, IL-12, IL-18 dan granulosit-makrofag faktor perangsang koloni, dilepaskan. Respons ini ditentang oleh sitokin anti-inflamasi, seperti IL-4, IL-10, IL-13, IFN-a dan faktor pertumbuhan yang berubah. Faktor nuklir-kB (NF-kB), faktor transkripsi, juga memainkan peran penting dalam respons inflamasi dengan mengatur ekspresi berbagai gen yang mengkode sitokin pro-inflamasi, molekul adhesi, kemokin, faktor pertumbuhan, dan enzim yang diinduksi seperti cyclooxygenase - 2 (COX2), diinduksi nitrit oksida sintase (iNOS) dan COX-2 keduanya merangsang produksi sejumlah besar mediator proinflamasi. Pada peradangan kronis, mekanisme pengaturan negatif tampaknya tidak berfungsi (Ashley, et al., 2012).

Pada penelitian Hasanah et al., (2011) pada tikus putih yang diberikan ekstrak rimpang kencur, diketahui bahwa semakin tinggi dosis ekstrak rimpang kencur yang diberikan maka semakin kecil persentase radang yang terjadi dan semakin tinggi pula persentase inhibisi radangnya atau semakin tinggi dosis ekstrak maka semakin baik efeknya sebagai antiinflamasi. Pengecualian terdapat pada ekstrak rimpang kencur 2 dengan dosis $36 \mathrm{mg} / \mathrm{kg}$ bobot badan, di mana pada dosis tersebut, ekstrak rimpang kencur 2 memberikan efek antiinflamasi yang sedikit lebih kecil (atau dapat dikatakan sama) dengan dosis $18 \mathrm{mg} / \mathrm{kg}$ bobot badan. Hal tersebut terjadi diperkirakan karena adanya pengaruh faktor homogenitas dari tikus yang digunakan, di antaranya adanya pengaruh perbedaan dalam berat badan, volume darah, dan luas jaringan tubuh tikus yang digunakan dalam penelitian.
Penelitian Ravi, et al., (2009) dan Linnet et al., (2010) menunjukkan bahwa waktu terbentuknya radang/edema akibat dari induksi karagenan terdiri dari dua fase. Fase pertama (early phase), yaitu 1-2 jam setelah injeksi karagenan, menyebabkan trauma akibat radang yang ditimbulkan oleh karagenan. Trauma tersebut disebabkan oleh pelepasan serotonin dan histamin ke tempat radang serta terjadi peningkatan sintesis prostaglandin pada jaringan yang rusak. Pada fase kedua (late phase), 3 jam setelah diinjeksi karagenan, terjadi pelepasan prostaglandin dan dimediasi oleh bradikinin, leukotrien, sel polimorfonuklear, dan produksi prostaglandin oleh makrofag. Berdasarkan penelitian tersebut, bila mengacu pada persentase penurunan radang oleh ekstrak rimpang kencur dimulai pada waktu pengamatan jam ke-1 sampai jam ke-2, diduga ekstrak rimpang kencur bekerja pada fase pertama (early phase), yaitu melalui penghambatan pelepasan mediator kimia serotonin dan histamin ke tempat terjadinya radang. Selain itu, juga menghambat sintesis prostaglandin yang merupakan mediator utama dari inflamasi. Penghambatan sintesis prostaglandin diduga dengan cara menghambat kerja siklooksigenase (COX) yang berfungsi merubah asam arakhidonat menjadi prostaglandin bila terjadi radang.

\section{Mekanisme Efek Anti Inflamasi dan Analgesik}

Beberapa ekstrak dan senyawa tanaman menunjukkan aktivitas anti-inflamasi dengan meningkatkan produksi anti-inflamasi IL-10, mengurangi produksi IL-6 atau TNF-proinflamasi, atau mengurangi ekspresi iNOS dan COX-2. Ekstrak meningkatkan sekresi TNF-a dan sekresi IL-10 secara bersamaan, sehingga tidak jelas apakah meningkatkan atau mengurangi peradangan. hormon kortisol antiinflamasi meningkatkan sekresi IL-10, mengurangi produksi IL-6 dan TNF-a, dan menghambat ekspresi iNOS. Khususnya, beberapa senyawa lebih efisien dalam pengurangan sekresi IL-6 dan TNFdibandingkan dengan kortisol (apigenin, capsaicin, chrysin, diosmetin, kampferol, lakolin, myricetin, naringenin, dan quercetin), senyawa-senyawa ini tidak secara bersamaan meningkatkan sekresi IL-10. Kortisol dan fungsi kortikosteroid lainnya terutama melalui menekan beberapa gen inflamasi yang terlibat dalam peradangan kronis (Umar et al., 2014).

Ekstrak kasar Kaempferia galanga $L$ telah dilaporkan memiliki sifat antiinflamasi dan 
analgesik. Namun, konstituen yang bertanggung jawab atas sifat-sifat ini dan mekanisme yang mendasari sifat-sifat ini belum dievaluasi. Dalam sebuah penelitian baru-baru ini, dilaporkan bahwa efek anti-inflamasi dari Kaempferia galanga $L$ terutama disebabkan oleh konstituen aktifnya, etil-p-metoksisinamat (EPMC). Hal ini merupakan laporan pertama tentang efek antiinflamasi EPMC yang diisolasi dari Kaempferia galanga $L$. Selain itu, dalam uji kolorimetri in vitro, EPMC telah terbukti menghambat aktivitas enzim COX-1 dan COX-2 dalam sistem bebas sel. Dalam sebuah studi baru-baru ini, efek penghambatan EPMC dan turunan tiourea dalam model fibrosarcoma tikus dilaporkan. Namun, beberapa data ilmiah memvalidasi efek antiinflamasi EPMC dalam model kronis in vivo tersedia, dan tindakan penghambatannya pada sitokin pro-inflamasi belum dilaporkan. Dalam laporan sebelumnya, efek penghambatan EPMC pada COX-1 dan COX-2 mendorong penulis untuk fokus pada penilaian efek analgesik yang mungkin menggunakan model in vivo. Inhibitor sitokin, terutama TNF-a, telah terbukti memiliki potensi anti-angiogenik yang kuat. Selain itu, penghambatan sintesis TNF-a telah terbukti mencegah aktivasi jalur NF-kB, yang diperlukan untuk sintesis protein angiogenik (Umar et al., 2014).

Mekanisme kerja etil p-metoksisinamat dan etil sinamat di Kaempferia galanga $L$. hampir sama dengan obat golongan NSAID dengan menghambat enzim siklooksigenase (COX) melalui metabolisme asam arakidonat yang menyebabkan penurunan sintesis prostaglandin (PG) yang timbul dari cedera pada jaringan. Prostaglandin ini adalah mediator inflamasi yang dapat menyebabkan tumor (pembengkakan) dan timbulnya nyeri (dolor). Dalam studi mekanistik antiinflamasi in vitro, EPMC ditemukan menghambat COX-1 dan COX-2 secara non-selektif. Selain penghambatan sintesis PG, Kaempferia galanga $L$ juga menghambat beberapa mediator inflamasi TNF- $\alpha$, IL-1 $\beta$, dan Nitric Oxide (NO) (Umar et al., 2012).

Fraksinasi yang dipandu bioassay dari Kaempferia parviflora, fraksi heksana menunjukkan aktivitas tinggi terhadap NO. Komponen dari Kaempferia parviflora juga diuji pada pelepasan PPS2 dan TNF-a yang diinduksi LPS. Terungkap bahwa dari Kaempferia parviflora menunjukkan efek penghambatan yang cukup besar pada rilis PGE2, tetapi tidak aktif pada pelepasan TNF-alfa). Selain. Itu, beberapa flavonoid aktif menekan induksi iNOS dengan cara yang tergantung pada dosis (Tewtrakul dan Subhadhirasakul, 2008).

EPMC melaporkan bahwa menghambat situs aktif enzimatik pada COX-1 dan COX-2, yang dapat berkontribusi terhadap efek analgesiknya. Meskipun ini adalah laporan pertama dari efek analgesik EPMC, laporan sebelumnya tentang efek analgesik ekstrak air Kaempferia galanga $L$ menyarankan bahwa efeknya melibatkan jalur analgesik opioid. Oleh karena itu, selain penghambatan jalur siklooksigenase, efek analgesik EPMC juga dapat dikaitkan dengan regulasi jalur opioid. Namun, penyelidikan lebih lanjut diperlukan untuk mengkonfirmasi hipotesis ini (Umar et al., 2012).

Nyeri merupakan pengalaman sensorik dan emosional yang tidak menyenangkan akibat adanya kerusakan jaringan yang berpotensi terjadi atau telah terjadi. Pada kerusakan jaringan, asam arakidonat akan dilepaskan dari membran fosfolipid dengan bantuan enzim fosfolipase. Asam arakidonat akan diubah menjadi prostaglandin endoperoksida (PGH) dengan enzim siklooksigenase (COX). Prostaglandin endoperoksida sintase-1(COX-1) terekspresi di kebanyakan sel dan berfungsi untuk proses fisiologis (maintenance), sedangkan PGH sintase-2 (COX-2) terekspresi bila terdapat stimulus yaitu saat terjadi inflamasi (Katzung, 2013). COX-2 yang terutama bertanggung jawab atas sintesis PG pada saat inflamasi akut dan kronis. Prostaglandin menyebabkan sensitasi neuron afferen (nosiseptor) pada stimulus kimia, suhu, dan mekanik (Bonica and Loeser, 2001). Obat analgesic menghambat enzim PGH sintase (COX). Penghambatan pada COX-2 akan memberikan efek antipiretik, analgesik, dan antiinflamasi, sedangkan penghambatan pada COX-1 akan memberikan efek samping pada traktus gastrointestinal (Gilman, et al., 2001). Kencur mengandung zat aktif p-metoksisinamat mempunyai efek menghambat ekspresi COX-2 serta menghambat mediator inflamasi: histamin, serotonin, IL-6, IL-1, PGE-2 (Hasanah et al., 2011). Kunyit mengandung zat aktif flavonoid kurkumin atau diferuloymethane (Dobelis, 2002). Flavonoid kurkumin dalam hal ini trietil curcumin (TEC) yang bersifat analgesik mempunyai efek menghambat metabolisme dari asam arakhidonat yaitu menghambat siklooksigenase dan lipooksigenase (Ayurini, 2010; Aggarwal dan Harikumar, 2009).

Mekanisme yang dilaporkan nampaknya disebabkan oleh efek analgesik sentral dan perifer dari konstituen aktif yaitu etil sinamat. Literatur juga mengusulkan mekanisme ekstrak 
Kaempferia galanga $L$ melalui penghambatan enzim siklooksigenase-2 (COX-2) dan sitokin proinflamasi yaitu interleukin-6 (IL-6). Aktivitas anti-inflamasi SKG-1 yang tercatat terhadap peradangan kronis mungkin terjadi melalui mekanisme ini (Jagadish, et al., 2016).

Angiogenesis telah sangat terlibat dalam perkembangan peradangan kronis, karena membantu dalam pemeliharaan perfusi jaringan dan meningkatkan lalu lintas seluler yang diperlukan untuk peradangan. Dengan demikian, penghambatan angiogenesis adalah target yang cocok untuk mengobati penyakit radang kronis. Selain itu, sitokin, terutama IL-1 dan TNF-a, telah ditemukan diproduksi pada tingkat tinggi di jaringan granulasi yang tumbuh cepat, yang telah disarankan untuk mempromosikan angiogenesis berlebihan. Telah dilaporkan bahwa makrofag meningkatkan angiogenesis dalam jaringan granulasi inflamasi melalui sitokin melalui produksi VEGF. Penelitian ini mengungkapkan bahwa sementara EPMC menekan produksi jaringan granulasi dalam pelet kapas, itu juga secara signifikan menghambat produksi VEGF dalam sel endotel manusia (Umar et al., 2012).

Kemampuan Aquous Extract Kaempferia galanga $L$ (AEKG) untuk menghambat uji penyempitan perut, yang melibatkan pelepasan prostasiklin bersintesis cyclooxygenase (COX), menunjukkan bahwa aktivitas yang diamati dapat sebagian disebabkan oleh penghambatan COX perifer. Kemampuan AEKG untuk menunjukkan aktivitas anti-inflamasi, selain dapat disebabkan oleh pemblokiran COX, juga dapat dikaitkan dengan aktivitas antioksidan tanaman. Edema yang dihasilkan oleh pemberian yang merupakan peristiwa bifasik dan dapat dibagi menjadi fase awal dan fase akhir. Fase akhir, khususnya, juga terkait dengan pelepasan radikal bebas oleh neutrofil (hidrogen peroksida, radikal hidroksil, dan superoksida) (Sulaiman et al., 2007).

Ekstrak metanol Kaempferia galanga $L$ juga mempunyai efek toksisitas yang cukup besar terhadap larva dan pupa Anopheles stephensi (Dhandapani, et al, 2011). Ekstrak etanol dari Kaempferia galanga L juga mempunyai aktifitas sebagai analgesik dan antiinflamasi (Mohanbabu, et al., 2011), ekstrak heksan dari Kaempferia galanga $L$ mempunyai aktifitas sebagai sedatif (Huang et al., 2008).

Uji analgetik ekstrak etanol kecil rimpang kencur (Kaempferia galanga L) pada mencit dengan metode geliat menunjukan bahwa penelitian mencit menurun dengan meningkatkan pemberian dosis pemberian kencur kedalam bentuk suspense ekstrak etanol kering rimpang kencur, sehingga dapat disimpulkan bahwa kencur memiliki sifat analgesik. Selain itu, uji efek etil para metoksi sinamat yang diisolasi dari rimmpang kencur. (Kaempferia galangal) pada mencit dengan metode Witkin menunjukkan bahwa sediaan etil para metoksi sinarmat dengan kadar $25 \mathrm{mg} / \mathrm{kg}$ BB, $50 \mathrm{mg} / \mathrm{kg}$ BB dan $\mathrm{mg} / \mathrm{kg}$ BB memberikan efek analgesic asetosal adalah sebesar $71 \%, 104 \%, 138 \%$.

Meskipun aktivitas antioksidan daun Kaempferia galanga $L$ belum terbukti, proses inflamasi disertai dengan peningkatan aktivitas radikal bebas dan kemampuan AEKG untuk mempromosikan aktivitas anti-inflamasi, itu adalah masuk akal untuk memasukkan sifat antioksidan tanaman sebagai salah satu mekanisme yang berkontribusi terhadap aktivitas anti-inflamasi yang diamati. Dalam hal mekanisme aksi yang terlibat, aktivitas antinosiseptif AEKG dapat dikaitkan dengan modulasi nitrat oksida sintase tipe 2 (NOS-2), protein tirosin kinase, jalur protein kinase $\mathrm{C}$, dan jalur L-arginin/NO oleh flavonoid. NOS-2 yang terlibat dalam sintesis NO telah dikaitkan dengan mekanisme antinosiseptif dan anti-inflamasi, sedangkan protein tyrosine kinase dilaporkan melibatkan ekspresi NOS-2. Di sisi lain, aktivitas anti-inflamasi AEKG disarankan karena kemampuan senyawa tersebut untuk menyebabkan efek vasodilatasi dan untuk memodulasi fosfolipase A2 dan fosfolipase C, COX, dan/atau jalur lipoksigenase (Sulaiman, et al., 2007).

\section{SIMPULAN}

Kaempferia galanga $l$ dapat digunakan sebagai alternatif antiinflamasi dan analgesik. mekanisme yang terjadi melalui penindasan respon antiinflamasi dan mediator proinflamasi.

\section{DAFTAR PUSTAKA}

Abbas, A. K., Lichtman, A. H., \& Pillai, S. (2015). Cellular and Molecular Immunology. Canada: Elsevier Inc.
Aggarwal \& Harikumar. (2009). Potential Therapeutic Effects of Curcumin, The AntiInflammatory Agent, Against Neurodegenerative, Cardiovascular, 
Pulmonary, Metabolic, Autoimmune and Neoplastic Diseases. United States: NCBI.

Ashley, N. T., Weil, Z. M., \& Nelson, R. J. (2012). Inflammation: Mechanisms, Costs, and Natural Variation. Annual Review Evol. Syst. 12(43): 385-406.

Asmara, A., Daili, S.F., Noegrohowati, T., \& Zubaedah, I. (2012). Vehikulum dalam Dermatoterapi Topikal. Jakarta: Departemen Ilmu Farmasi Kedokteran FKUI.

Ayurini, B. D. (2010). Pengaruh Ekstrak Etanol Rimpang Kunyit (Curcuma domestica Val) terhadap Jumlah Geliatan Mencit BALB/C yang Diinjeksi Asam Asetat 0,1\%. [Tesis]. Semarang: Universitas Diponegoro.

Bengmark, S. (2006). The Effect of Curcumin (Active Substance of Turmeric) on the Acetic-Acid Induced Visceral Nociception in Rats. J of Bio Sci. 11(2): 312-314.

Bonica, J.J. \& Loeser, J. D. (2001). History of Pain Concepts and Therapies. Philadelphia: Lippincott William and Wilkins.

Buang, A. (2012). Uji Efek Anti Inflamasi Salep Ekstrak Etanol Rimpang Kunyit (Curcuma domestica rhizoma) terhadap Mencit (Mus musculus). J Media Farm. 9(16): 10-14.

Dhandapani, A., Kumar, S., \& Kadarkarai, M. (2011). Larvicidal, Pupicidal and Smoke Toxicity Effect of Kaempferia Galanga to the Malarial Vector, Anopheles Stephensi. The BioScan J. 6(2): 329-333.

Dobelis. (2002). Curcuma longa. United states: Thorne Research, Inc.

Erlina, R., A. Indah, dan Yanwirasti. (2007). Efek Antiinflamasi Ekstrak Etanol Kunyit (Curcuma domestica Val.) pada Tikus Putih Jantan Galur Wistar. J. Sains dan Tekno Farm. 12(2): 112-115.

Gilman A.G., Hardman, J. G., \& Limbird, L. E. (2001). The Pharmacological Basis of Therapeutics. New York: McGraw-Hill Medical Publishing Division.

Hasanah, N., Nazaruddin, F., Febriana, E., \& Zuhrotun, A. (2011). Analisis Kandungan Minyak Atsiri dan Uji Aktivitas Antiinflamasi Ekstrak Rimpang Kencur (Kaempferia galanga L). J Matematika dan Sains. 16(3): 107-112.

Huang, L., Yagura, T., \& Chen, S. (2008). Sedative activity of hexane extract of Kaempferia galangal $L$. and its active compound. J of Ethnopharm. 120(1): 123125.

Izzany, F., Bakar, A., Fadzelly, M., Bakar, A., Abdullah, N., Endrini, S., \& Rahmat, A.
(2018). A Review of Malaysian Medicinal Plants with Potential Antidiabetic. Advances in Pharmacological Sciences. 10: 1-13.

Jagadish, P. C., Latha, K. P., Mudgal, J., \& Nampurath, G. K. 2016. Extraction, characterization and evaluation of Kaempferia galanga L. (Zingiberaceae) rhizome extracts against acute and chronic inflammation in rats. $J$ of Ethnopharm. 194(2): 434-439.

Katzung, B. G., Enthony, J. T., \& Susan, B. M. (2013). Pharmacology: Examination and Board Review. $5^{\text {th }}$ edition. United States: Lange Medical Book Mc. Graw-Hill.

Kusumawati, I., \& Yusuf, H. (2011). Phospholipid Complex as a Carrier of Kaempferia Galanga Rhizome Extract to Improve Its Analgesic Activity. Int $J$ of Pharm and Pharm Sci. 3(1): 1-3.

Linnet, A., Latha, P. G., Gincy, M. M., Anuja, G. I., Suja, S. R., \& Shymal, S. (2010). Antiinflammatory, Analgesic, and Anti-lipid Peroxidative Effects of Rhaphidophora pertusa (Roxb.) and Epipremnum pinnatum (Linn.) Engl. aerial parts. Indian J Nat Prod and Res. 1(1): 5-10

Majeed. (1995). Curcuminoids Antioxidant Phytonutrients. New Jersey: Nutrisciecs Publisher Inc.

Mohanbabu, V. A., Shanbhag, T., K. Kumari, M., Bairy, K. L., \& Shenoy S. (2011). Evaluation of Antiinflammatory and Analgesic Activities of Alcoholic Extract of Kaempferia Galanga in Rats. Indian $J$ Physiol Pharmacol. 55(1): 13-24.

Mueller, M., Hobiger, S., \& Jungbauer, A. (2010). Anti-inflammatory activity of extracts from fruits, herbs and spices. $J$ Food Chemistry. 122(4): 987-996.

Othman, R., Ibrahim, H., Mohd, M. A., Mustafa, M. R. \& Awang, K. (2006). Bioassayguided isolation of a vasorelaxant active compound from Kaempferia galangal L. $J$ of Phytomed. 13(1): 61-66.

Ravi V., Saleem, T. S. M., Patel, S. S., Raamamurthy, J., \& Gauthaman, K (2009). Anti-Inflammatory Effect of Methanolic Extract of Solanum nigrum Linn. Berries. Int J App Res Nat Prod. 2(2): 33-36.

Riasari, H., Rachmaniar, R., \& Febriani, Y. (2016). Effectiveness of AntiInflammatory Plaster from Kencur (Kaempferia galanga L.) Rhizome Ethanol Extract. Int J of Pharm Sci and Res. 7(4): 1746-1749. 
Rostiana, O., Abdullah, A., Taryono, \& Haddad, E. A. (2003). Jenis-jenis Tanaman Obat. Jakarta: Penelitian Tanaman Rempah dan Obat.

Sukmono, R. J. (2009). Mengatasi Aneka Penyakit dengan Terapi Herbal. Jakarta: Agromedia Pustaka.

Sulaiman, M. R., Zakaria, Z. A., Daud, I. A., Ng, F. N., Ng, Y. C., \& Hidayat, M. T. (2007). Antinociceptive and anti-inflammatory activities of the aqueous extract of Kaempferia galanga leaves in animal models. J of Nat Med. 62(2): 221-227.

Tara, V., Shanbag, Candrakala, S., Sachidananda, A., Kurady, B. L., Smita, S., \& Ganesh, S. (2006). Wound Healing Activity of Alkoholic Extract of Kaempferia galanga in Wistar Rats. Indian $J$ Physiol Pharmacol. 50(4): 384-390.

Tewtrakul, S., \& Subhadhirasakul, S. (2008). Effects of compounds from Kaempferia parviflora on nitric oxide, prostaglandin E2 and tumor necrosis factor-alpha productions in RAW264.7 macrophage cells. J of Ethnopharm. 120(1): 81-84.

Umar, M. I., Asmawi, M. Z., Sadikun, A., Atangwho, I. J., Yam, M. F., Altaf, R., \& Ahmed, A. (2012). Bioactivity-guided isolation of ethyl-p-methoxycinnamate, an anti-inflammatory constituent, from Kaempferia galanga L. extracts. $J$ of Molecules. 17(7): 8720-8734.

Umar, M., Asmawi, M., Sadikun, A., Majid, A., Al-Suede, F., Hassan, L., Ahamed, M. (2014). Ethyl-p-methoxycinnamate isolated from kaempferia galanga inhibits inflammation by suppressing interleukin1 , tumor necrosis factor- $\alpha$, and angiogenesis by blocking endothelial functions. J of Clinics. 69(2): 134-144.

Vittalrao, Mohanbabu, A., Shanbhag, T., Kumari, K. M., Bairy, K. L., \& Smita S. (2011). Evaluation of Antiinflammatory and Analgesic Activities of Alcoholic Extract of Kaempferia Galanga in Rats. Indian J of Phys and Pharm. 55(1): 13-24. 